Ісраел Олувасейідайо Ідріс аспірант кафедри державного управління, публічного адміністрування та регіональної економіки, Харківський національний економічний університет ім. С. Кузнеця, просп. Науки, 9-А, м. Харків, 61166, тел..: (056) 702-18-34, e-mail: idrisseyidayo@yahoo.co.uk, https://orcid.org/0000-0002-9626-2309

Джаін Прадіп Кумар аспірант кафедри державного управління, публічного адміністрування та регіональної економіки, Харківський національний економічний університет ім. С. Кузнеця, просп. Науки, 9-А, м. Харків, 61166, тел..: (056) 702-18-34, e-mail: ngavl@ukr.net, https://orcid.org/0000-0002-5195-1311

\title{
УПРАВЛІННЯ ТА ПОЛІПШЕННЯ ЯКОСТІ РЕЗУЛЬТАТІВ СИСТЕМИ ОХОРОНИ ЗДОРОВ'Я
}

Анотація. У статті визначено значення системи управління та належного управління в системі охорони здоров'я. Це показує, що взаємозв'язок управління та здоров'я є циклічним. Таким чином, належне врядування покращує сектор охорони здоров'я, що, в свою чергу, покращує управління та сприйняття управління. Встановлено необхідність адекватного формулювання та реалізації політики, а також важливість створення належного механізму управління, який передбачає широкі відносини між секторами, особами, постачальниками, організаціями, структурами, механізмами та державою. Охарактеризовано основні елементи побудови належного управління, а саме: інформація про охорону здоров'я, фінансування охорони здоров'я, надання медичних послуг, людські ресурси/робоча сила у галузі охорони здоров'я та необхідні ліки. Також визначено якості належного врядування в галузі охорони здоров'я та переваги, які приносить громадянам та системі охорони здоров'я будь-якої країни. Переваги включають довіру громадян до медичної служби та патронаж медичних центрів по всій країні. Досліджено засоби, за допомогою яких можна оцінити належне управління системою охорони здоров'я. Це можна спостерігати при реагуванні системи на питання, тому важливо оцінити цілі політики, інфраструктуру, створену для досягнення цих цілей, та результати для здоров'я 3 точки зору впливу громади, профілактики захворювань та якість життя в країні. Подібним чином, моделі прийняття рішень, що базуються на фактичних даних, повинні використовуватися в поєднанні з моделлю економічної ефективності, 
оскільки модель, що базується на фактичних даних, виступає за наукову оцінку альтернатив поряд із історичним контекстом, щоб гарантувати, що запланована політика чи втручання обов'язково досягнуть бажаних результатів . Ця стратегія також спрямована на те, щоб переконатися, що політика та втручання $\epsilon$ придатними для суспільного використання. У цій главі також було визначено охорону здоров’я та управління в українському контексті, проаналізувавши складний історичний, структурний та фінансовий фон, що породив сучасну систему.

Ключові слова: охорона здоров’я, управління, система управління, медичні послуги, обслуговування.

Israel Oluwaseyidayo Idris Graduate student of the Department of Public Administration, Public Administration and Regional Economy, Simon Kuznets Kharkiv National University of Economics, Nauky Ave., 9-A, Kharkiv, 61166, tel.: (056) 702-18-34, e-mail: idrisseyidayo@yahoo.co.uk, https://orcid.org/0000-0002-9626-2309

Jain Pradeep Kumar Graduate student of the Department of Public Administration, Public Administration and Regional Economy, Simon Kuznets Kharkiv National University of Economics, Nauky Ave., 9-A, Kharkiv, 61166, tel.: (056) 702-18-34, e-mail: ngavl@ukr.net, https://orcid.org/0000-0002-5195-1311

\section{MANAGING AND IMPROVING THE QUALITY OF HEALTHCARE RESULTS}

Abstract. The statistic designates the value of the management system and proper management in the health protection system. I will show you how the interconnection of management and health is cyclic. With such a rank, I will properly paint the health protection sector, and, in my own circle, I will paint the management and control. The need for an adequate formulation and implementation of policy has been established, as well as the importance of establishing a proper management mechanism, which transferring a wide range of different sectors, persons, managers, organizations, structures, mechanisms of that state. The main elements of motivation for proper management are characterized, and the following: information about health protection, financing of health protection, provision of medical services, human resources / work force from the health care provider and the necessary skills. It is also meant to be a good fit in the galuze to protect the health of those passages, as to bring to the masses that system to protect the health of the land. Perevagi include the support of the huge people to the medical service and the patronage of medical centers throughout the country. Doslidzheno zasobi, for the help of which you can assess the proper 
management of the health protection system. The price can be promoted when the system is responsive to nutrition, it is important to assess the goals of politics, infrastructure, and to achieve these goals, that results for health from the point of view of the inflow of the community, prevention of illness and the quality of life. Let us take the rank, the model accepted the decision, which is based on the actual tributes, which are guilty of the vicarists; 'it is easy to achieve good results. The strategy is also tailored to those who will change, but the policy is also attached to the suspicious victorian. At the same head, the protection of health and management in the Ukrainian context was also assigned, having analyzed the folding historical, structural and financial background, which gave rise to a fortuitous system.

Keywords: health protection, management, management system, medical services, service.

Постановка проблеми. У 2015 році Уряд України ініціював трансформаційну реформу системи охорони здоров'я з метою поліпшення стану здоров'я населення та забезпечення фінансового захисту від надмірних витрат «з кишені» шляхом підвищення ефективності, модернізації застарілої системи надання послуг та покращення доступу до якісного медичного обслуговування. Комплексна стратегія передбачала першочергове здійснення реформи фінансування системи охорони здоров'я для того, щоб прискорити перетворення у сфері надання медичних послуг (як для окремих осіб, так і для населення) та впровадити інформаційні технології в якості каталізаторів. Стратегія фінансування системи охорони здоров'я була сформульована в концептуальному документі, який був затверджений Кабінетом Міністрів України [1]. У жовтні 2017 року парламент ухвалив новий Закон України «Про державні фінансові гарантії медичного обслуговування населення» [2]. Підвищення якості розглядається як зразкова діяльність, орієнтована на дані, структурована таким чином, щоб миттєво покращити надання медичної допомоги в певних умовах. Ключові особливості вдосконалення включають: знання роботи 3 точки зору процесів та системи, групи постачальників медичних послуг та пацієнтів, які винаходять і знаходять рішення, зосередженість на потребах пацієнтів, спільне навчання, тестування та вимірювання ефектів модифікацій в системі надання послуг та процесів. Поліпшення якості $є$ важливим для досягнення набагато покращених медичних результатів, хоча це може бути складним та знеохочуючим, якщо акцент буде зроблено в контексті UHC. Кілька урядів пов'язують покращення якості з високою вартістю. Часто бракує ясності щодо ролей та обов'язків щодо здійснення та управління діяльністю 3 підвищення якості.

Якість управління повинна спочатку починатися з бачення. Визначаючи 
національне бачення якості, обов'язково думати про велике, але починати 3 малого. Бачення буде діяти як керівництво для досягнення успіху в системі охорони здоров'я. Однак бачення - це одна з багатьох частин, яка сприяє забезпеченню та просуванню якісної допомоги. Важливо чітко визначене бачення, яке може зрозуміти кожен. Цього можна досягти за допомогою національної політики якості, тактики та інших методів, таких як структура. Це можуть бути дуже потужні інструменти, які будуть корисні, якщо їх розроблятимуть у відповідності до загальних пріоритетів охорони здоров'я країни та будуть дотримуватися реалій місцевого контексту. Сам факт нехтування включенням якісної медичної допомоги як пріоритету політики або як частини розробки політики та визначення базового рівня якісної медичної допомоги ускладнює встановлення впливу політики на якість медичної допомоги.

Аналіз останніх досліджень і публікацій. Тематиці управління в охороні здоров'я присвячені роботи таких українських науковців, як Борщ В.I., Вороненко Ю.В., Літвак А., Москаленко В.Ф., Устінова О.В. Проте, ці науковці розглядають стратегічне управління закладами охорони здоров'я або системою охорони здоров'я загалом, не наголошуючи на нагальній потребі управління якістю медичних послуг.

Метою статті $\epsilon$ формування теоретичних засад стратегічного управління якістю системи охорони здоров’я в сучасних умовах господарювання.

Виклад основного матеріалу. Проблема управління якістю системи охорони здоров'я наразі стоїть дуже гостро в умовах національної системи охорони здоров'я у зв'язку з реформою галузі охорони здоров'я, а також пандемії COVID-19. Якість медичних послуг є дуже складним багатогранним поняттям, при управлінні яким необхідною умовою є врахування численних чинників, що в свою чергу, потребує стратегічного управління. Можна виокремити вісім ключових механізмів для покращення якості управління медичними послугами:

1. керування якістю за допомогою політики, стратегії та інших методів;

2. застосування використання регуляторних засобів для підвищення якості догляду;

3. узаконення недержавної участі в пошуку орієнтованої на людей якісної допомоги;

4. збирання політичного бажання переслідувати якість;

5. приєднання якості до фінансування;

6. вимірювання та використання даних для поліпшення якості;

7. розвиток культури розвитку якості;

8. виправляється розрив у знаннях щодо якості надання медичної допомоги на різних рівнях;

Складний стан системи охорони здоров’я та вплив відповідного управління 
та вироблення політики на зміцнення здоров'я та зменшення вартості медичного обслуговування призвели до того, що все більше уваги приділяється концепції належного управління в системі охорони здоров'я на міжнародному рівні, але визначення іï все ще знаходиться на іï базовій стадії і потребує обстеження [3]. Однак консенсус полягає у тому, що дискусія про належне управління в системі охорони здоров'я полягає у розробці політики та інфраструктури, яка відповідатиме потребам людей. Беручи до уваги кардинальні зміни, які були внесені в управління охороною здоров'я шляхом модернізації та глобалізації, важливо забезпечити, щоб система надавала якісний догляд, а також відповідала потребам людей.

В рамках ВООЗ щодо реагування зазначено, що, ставлячи запитання “Для кого призначена система охорони здоров'я?”, Ми можемо визначити цілі систем охорони здоров'я загалом, оскільки система охорони здоров'я зацікавлена у задоволенні потреб людей. Для задоволення цих потреб необхідно враховувати три цілі:

1. Здоров'я;

2. Чесне фінансування та захист фінансових ризиків;

3. Чуйність [4].

Швидке реагування - це аспект охорони здоров'я, заснований на споживачах, який спрямований на те, щоб забезпечити гідне ставлення до споживачів медичних послуг, терпляче, адекватну інформацію, негайну увагу, доступ до соціальної підтримки, вибір постачальників та основні зручності належної якості. У цьому ж ключі реагування може бути використано для оцінки ефективності системи охорони здоров'я щодо ії цілей, тому, оцінюючи систему охорони здоров’я в будь-якій країні, ми повинні враховувати надання послуг, інфраструктуру охорони здоров'я, результати охорони здоров'я, програми профілактики та зміцнення здоров'я у громадах [5]. У розвинених країнах дослідження показують, що реагуюча система охорони здоров'я мотивує дотримання споживачами медичних процедур, чесність та відкритість у постачальників медичних послуг та постійне використання медичних послуг. Подібним чином, у менш розвиненому світі задоволеність споживачів реагуючими послугами стимулює споживання доступних медичних послуг.

Факти також свідчать про те, що реагування в системі охорони здоров'я має користь саме для себе, незалежно від іï впливу на здоров'я населення [5]. Високий рівень реагування системи охорони здоров'я безпосередньо пов'язаний i3 належними структурами управління, які в основному працюють на основі доказових моделей формулювання політики [6]. Отже, цей документ аргументує прийняття ідеї прийняття рішень, що грунтуються на фактах, в системі управління охороною здоров'я.

Беручи до уваги той факт, що на управління системою охорони здоров’я 
може впливати політичний, культурний та економічний контекст країни, важливо, щоб будь-яка держава, відповідно до своїх традиційних умов, мала модель свого рішення - процес виготовлення, особливо в галузі управління охороною здоров'я. У цій роботі розглядається лише непрограмоване прийняття рішень, яке зазвичай використовується в новому або химерному контексті, а не запрограмоване прийняття рішень бачиться у шаблонній оперативній діяльності організацій, де потік роботи завжди однаковий. Розуміння того, як актори взаємодіють у непрограмованому контексті прийняття рішень, визначає результати його управління в галузі охорони здоров'я. Процеси прийняття рішень в галузі охорони здоров'я беруть участь як державних, так i недержавних суб'єктів, які зазвичай виконують різні ролі в підпроцесах: виявлення проблем, розробка політики, альтернативи політики, реалізація та оцінка [7].

Як видно з таблиці 1, (Р5) суб'єкти політики повинні виділяти більше ресурсів на підтримку наукових кіл, наукові кола (R1), з іншого боку, повинні спонтанно проводити дослідження щодо національних питань охорони здоров'я та рішень, тоді як медичні працівники (H1) повинні приймати дослідження у своїй практиці для перегляду доказів. Стрілки маррона представляють основні якості, необхідні кожному акторові для процесу прийняття рішень на основі доказів. Вплив ЗМІ необхідний, оскільки він представляє інтереси суспільства $\mathrm{i}$ служить шахом для акторів, щоб забезпечити максимальну підзвітність та прозорість для громадян. Ця структура серед інших рекомендацій цього дослідження може служити базовим правилом для країни у досягненні належного управління охороною здоров'я.

\section{Таблиия 1}

\section{Схема оцінки фінансування охорони здоров'я}

\begin{tabular}{|c|c|}
\hline Структурні домени & Операційні домени \\
\hline $\begin{array}{l}\text { Політики } \\
\text { (фінансування } \\
\text { охорони здоров’я) }\end{array}$ & 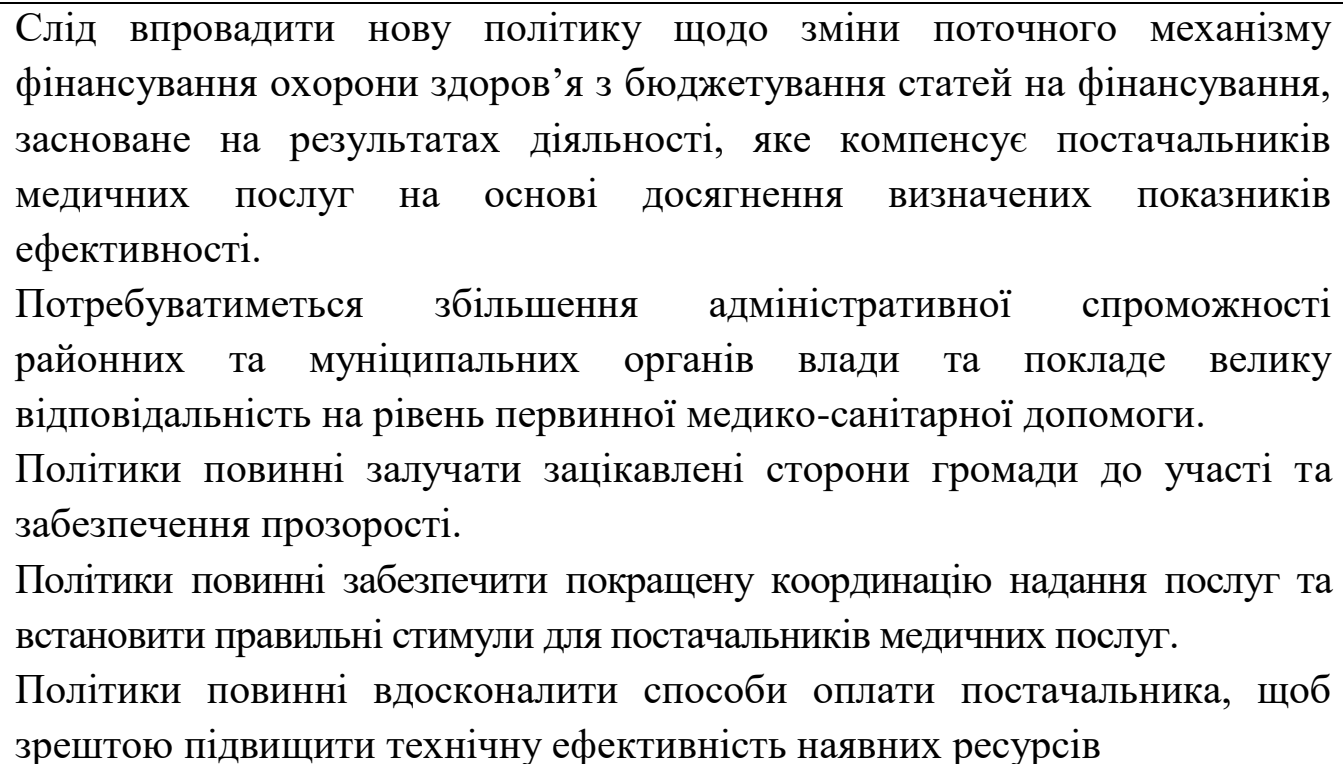 \\
\hline
\end{tabular}




\begin{tabular}{|c|c|}
\hline Дослідники & $\begin{array}{l}\text { Академіки повинні інвестувати в дослідження, щоб визначити найбільш } \\
\text { підходящу форму оплати послуг, перспективну чи ретроспективну, } 3 \\
\text { найменшою кількістю мінусів. } \\
\text { Дослідникам слід вивчити рецензовані журнали на відповідність методам } \\
\text { стратегічних закупівель, що стимулюватиме постачальників медичних } \\
\text { послуг до поліпшення якості медичної допомоги. } \\
\text { Для дослідників важливо встановити способи зменшення ризику, який } \\
\text { несуть як платники, так і постачальники, щоб зменшити проблеми }\end{array}$ \\
\hline $\begin{array}{l}\text { Громадянські } \\
\text { суспільства }\end{array}$ & $\begin{array}{l}\text { Громадянські суспільства зобов'язані брати активну участь у } \\
\text { забезпеченні прозорості фінансування охорони здоров'я у всіх кадрах та } \\
\text { секторах. } \\
\text { Учасники громадянського суспільства повинні брати участь у процесі } \\
\text { прийняття рішень для підвищення інклюзивності та відображати } \\
\text { фактичну ситуацію в підходах знизу. } \\
\text { Громадянські суспільства представляють форму здорової опозиції і } \\
\text { життєво необхідні для надання іншої корисної перспективи формуванню } \\
\text { політики щодо механізмів оплати послуг постачальників }\end{array}$ \\
\hline $\begin{array}{l}\text { Постачальники } \\
\text { медичних послуг }\end{array}$ & $\begin{array}{l}\text { Постачальники медичних послуг повинні забезпечити використання } \\
\text { механізму платежів, який не перекладає всіх ризиків на платників } \\
\text { (фізичних осіб, медичні страхові установи чи уряд). } \\
\text { Лікарі повинні гарантувати, що вони не втягують моральну небезпеку, } \\
\text { надаючи пацієнтам належну якісну медичну допомогу, і не збільшують } \\
\text { їх переваги. } \\
\text { Лікарі повинні прагнути не брати участь у виборі ризику та відвертати } \\
\text { пацієнтів, щоб збільшити дохід }\end{array}$ \\
\hline $\begin{array}{l}\text { Міжнародні } \\
\text { неурядові } \\
\text { організації }\end{array}$ & $\begin{array}{l}\text { Міжнародні НУО (МНП) повинні сприяти механізмам оплати послуг } \\
\text { постачальників, щоб взяти на себе частину ризику, який несе платник та } \\
\text { постачальник. } \\
\text { МНП повинні брати участь у процесах прийняття рішень щодо } \\
\text { визначення методів оплати послуг постачальника для забезпечення } \\
\text { прозорості та інклюзивності. } \\
\text { МНП повинні прагнути залучити усіх відповідних зацікавлених сторін, } \\
\text { щоб гарантувати, що обраний постачальник механізмів платежів виграє } \\
\text { від усіх і розподіляє ризик як можна порівну }\end{array}$ \\
\hline $\begin{array}{l}\text { Приватні медичні } \\
\text { організації } \\
\text { (наприклад, } \\
\text { медичне } \\
\text { страхування) }\end{array}$ & $\begin{array}{l}\text { Приватні організації повинні сприяти оптимальному збору даних та } \\
\text { аналізу навколишніх механізмів оплати послуг провайдерів для } \\
\text { вдосконалення послуг та виявлення порушень у наданні послуг. } \\
\text { Агенції медичного страхування повинні сприяти адекватній оплаті } \\
\text { послуг тих постачальників, які не покладають ризик на платника або тих, } \\
\text { хто надає послуги, тим самим зменшуючи ймовірність моральної } \\
\text { небезпеки }\end{array}$ \\
\hline
\end{tabular}

У таблиці 2 наведено систематичний спосіб досягнення виграшів для громадян, які визнають здоров'я як право людини для своїх громадян завдяки доброму врядуванню. Це також повторно постулювало, що суб'єкти управління в 
галузі охорони здоров'я повинні бути міжгалузевими, що вимагає формування політики у цих сферах, включаючи міністерство транспорту та торгівлі, щоб регулярно розглядати результати своєї політики в галузі охорони здоров'я: користь, шкода та витрати на здоров'я.

Таблиия 2

\section{Запропонований процес ефективного прийняття рішень на основі фактичних даних}

\begin{tabular}{|c|c|}
\hline Структурні домени & Операційні домени \\
\hline Політики (Р) & 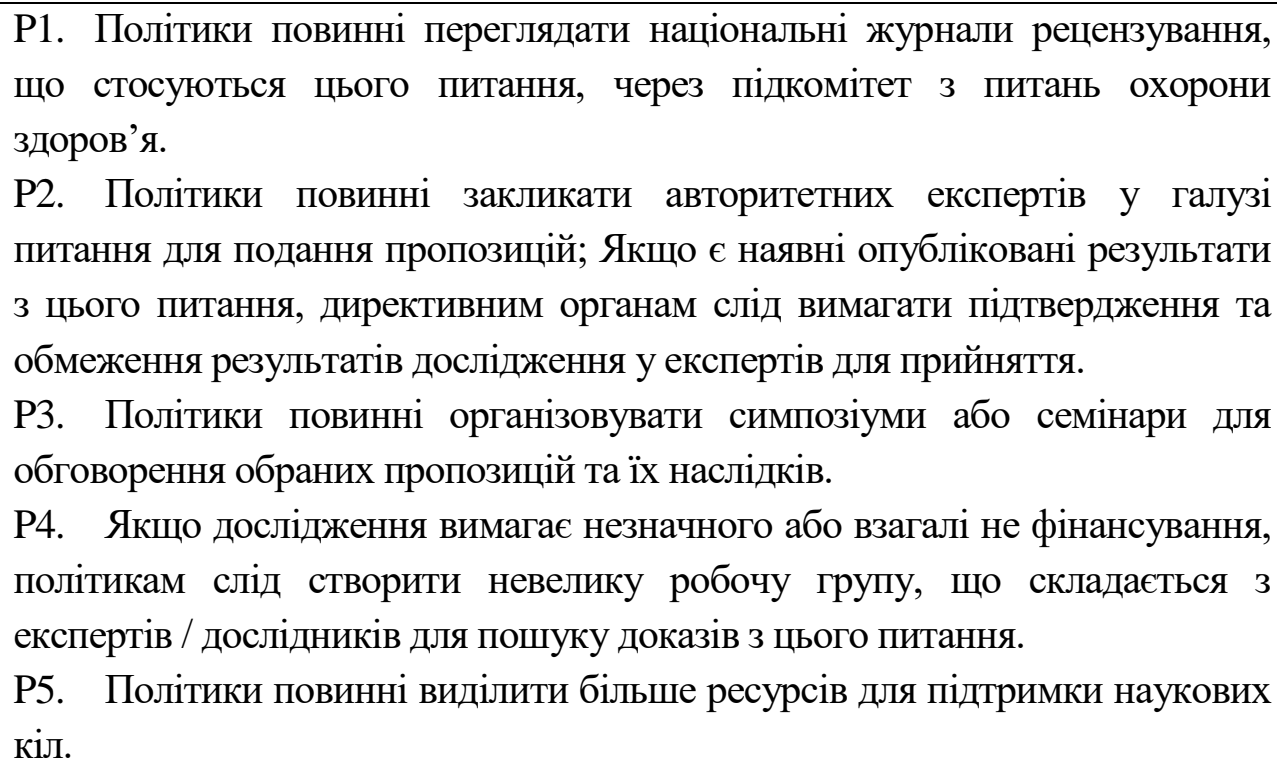 \\
\hline & $\begin{array}{l}\text { R1. Дослідники / Академії повинні взаємодіяти з іншими науковими } \\
\text { колами / дослідниками для обговорення та проведення досліджень } \\
\text { щодо національних питань охорони здоров'я та рішень. } \\
\text { R2. Дослідникам слід публікувати результати досліджень та } \\
\text { поширювати їх серед публіки через блоги чи газети. } \\
\text { R3. Якщо дослідження стосуються нагальної національної проблеми, } \\
\text { дослідники повинні надсилати перекладені результати досліджень } \\
\text { розробникам політики через свої наукові кола / установи. }\end{array}$ \\
\hline $\begin{array}{l}\text { Постачальники } \\
\text { медичних послуг (H) }\end{array}$ & $\begin{array}{l}\text { Н1. Заклади охорони здоров’я повинні застосовувати дослідження у } \\
\text { своїй практиці для перегляду доказів. } \\
\text { Н2. Постачальники медичних послуг також повинні бути навчені } \\
\text { бачити себе адвокатами пацієнтів при прийнятті рішень на } \\
\text { національному рівні. }\end{array}$ \\
\hline $\begin{array}{l}\text { Приватні організації, } \\
\text { особливо } \\
\text { фармацевтичні } \\
\text { компанії, такі як Pfizer }\end{array}$ & $\begin{array}{l}\text { 1. Приватним органам слід активізувати співпрацю із закладами } \\
\text { охорони здоров'я та науковими колами. } \\
\text { 2. Приватні органи також повинні брати участь у семінарах з питань } \\
\text { охорони здоров'я. } \\
\text { 3. Приватні організації повинні підтримувати ресурси у пошуку } \\
\text { доказів. } \\
\text { 4. Приватні органи повинні поділяти можливість справедливості } \\
\text { рішення. }\end{array}$ \\
\hline
\end{tabular}




\begin{tabular}{|c|c|}
\hline & $\begin{array}{l}\text { 1. Місцеві НУО та соціальні групи повинні законно представляти } \\
\text { громаду / пацієнтів щодо впливу на рішення громади. } \\
\text { 2. Місцеві НУО повинні легко надавати інформацію дослідникам } \\
\text { про суспільні погляди, цінності, вартість та культурні норми } \\
\text { прийнятності. } \\
\text { 3. Місцеві НУО та соціальна група повинні виступати свідками, } \\
\text { брати участь та контролювати процес прийняття рішень }\end{array}$ \\
\hline $\begin{array}{l}\text { Зовнішні / } \\
\text { міжнародні } \\
\text { фінансування та } \\
\text { МНП(Е) }\end{array}$ & $\begin{array}{l}\text { 1. Місцеві НУО та соціальні групи повинні законно представляти } \\
\text { громаду / пацієнтів щодо впливу на рішення громади. } \\
\text { 2. Місцеві НУО повинні легко надавати інформацію дослідникам } \\
\text { про суспільні погляди, цінності, вартість та культурні норми } \\
\text { прийнятності. } \\
\text { 3. Місцеві НУО та соціальна група повинні виступати свідками, } \\
\text { брати участь та контролювати процес прийняття рішень }\end{array}$ \\
\hline
\end{tabular}

3 огляду на світову інфляцію та постійне збільшення національних видатків на охорону здоров'я, зростає акцент на мінімізації витрат та максимізації якості медичних послуг. Політики та медичні працівники повинні враховувати загальну користь, яку матиме країна від участі у певних політиках. Це визначає необхідність економічної оцінки у секторі охорони здоров'я. Охорона здоров'я та управління стали свідками зростаючого інтересу до економіки охорони здоров'я та економічної оцінки, оскільки було виявлено, що економічна оцінка в рамках заходів охорони здоров'я може бути вирішальним фактором у запобіганні катастрофам та врегулюванні криз. Формулюючи політику охорони здоров'я, рамки належного управління завжди враховують наявність ресурсів з точки зору людських ресурсів, інфраструктури та капіталу. Хоча ці три $є$ важливими факторами, на основі яких визначається успіх систем охорони здоров'я, функція належного управління полягає у пошуку економічно ефективного поєднання трьох. Що стосується управління ресурсами, що стосуються цілей політики, то тут слід зробити важкий вибір. Цей вибір в ідеалі повинен зайняти час, щоб раціонально врахувати потенційні вигоди, ризики та вимоги до капіталу будь-якої альтернативи. Це створює труднощі з набуттям інформації, що $є$ вирішальним для забезпечення оптимального формулювання політики системи охорони здоров'я.

Висновки. Обгрунтовано, що результати належного врядування в галузі охорони здоров'я покращують загальну систему охорони здоров'я. Це дослідження довело, що належне врядування у галузі охорони здоров'я призводить до справедливого розподілу фінансів, покращення мотивації персоналу та ефективного управління, чітке визначення ролей ключових суб'єктів, включаючи уряд, медичних працівників та громадян. Управління $\epsilon$ важливим фактором результатів діяльності систем охорони здоров'я, оскільки 
воно впливає на сектор охорони здоров'я як безпосередньо, так і опосередковано. Це безпосередньо впливає на бюджет, формулювання політики та інфраструктуру в системі. Побічно це впливає на систему через позитивний вплив доходу та загальної якості системи охорони здоров'я.

Для забезпечення сталості реформи важливо забезпечити розподіл відповідальності за іï проведення між основними зацікавленими сторонами, включаючи місцеві органи влади, надавачів послуг та населення.

\section{Лimepamypa:}

1. Розпорядження Кабінету Міністрів «Про схвалення Концепції реформи фінансування системи охорони здоров’я» № 1013-p. https:// www.kmu.gov.ua/ua/npas/249626689, станом на 22 серпня 2019 року,

2. Закон України «Про державні фінансові гарантії медичного обслуговування населення» № 2168-VIII. https://zakon.rada.gov.ua/laws/ show/2168-19, станом на 22 серпня 2019 року.

3. Борщ В. І. Особливості імплементації механізмів стратегічного менеджменту в закладах охорони здоров'я України. Актуальные проблемы современной науки: сборник тезисов научных трудов XIII Международной научно-практической конференции (ХарьковВена-Берлин-Астана, 29 августа 2019 года). Международныи научный центр развития науки и технологии , 2019. С. 53-56.

4. Вороненко Ю. В. Стратегічне управління в охороні здоров'я: теоретичні та практичні аспекти. Науковий журнал МОЗ України. 2014. № 5 (1). С. 39-46.

5. Данченко О. Б., Ленський В. В. Моделі стратегічного менеджменту медичних проектів проектно-орієнтованого медичного закладу. Вісник Національного технічного університету «ХПІ». Серія: Стратегічне управління, управління портфелями, програмами та проектами. 2018. № 2 (1278). C. 45-52.

6. Сафонов Ю. М., Борщ В. І. Стратегічний менеджмент закладів охорони здоров’я України: принципи та особливості застосування в галузі охорони здоров'я України. Актуальні проблеми економіки. 2019. № 8 (218). С. 62-69.

7. Abdulaziz Saddique Strategic management of Healthcare Organizations. 2015. URL: https://www.researchgate.net/publication/276019548_Strategic_management_of_Healthcare_Organizations

\section{References:}

1. Rozporyadzhennya Kabinetu Ministriv «Pro skhvalennya Kontseptsiyi reformy finansuvannya systemy okhorony zdorov"ya» [Order of the Cabinet of Ministers "On approval of the Concept of health care financing reform"]. (2019, August 22) № 1013-r. kmu.gov.ua/ua/npas/249626689 (Retrieved from https: // www.kmu.gov.ua/ua/npas/249626689 [in Ukrainian].

2. Zakon Ukrayiny «Pro derzhavni finansovi harantiyi medychnoho obsluhovuvannya naselennya» [Law of Ukraine "On state financial guarantees of medical care"]. 2019, August 22) № 2168-VIII. zakon.rada.gov.ua/laws/show/2168-19 Retrieved from https://zakon.rada.gov.ua/laws/ show/2168-19 [in Ukrainian].

3. Borshch, V. I. (2019). Osoblivostí ímplementatsî́ mekhanízmív strategíchnogo menedzhmentu v zakladakh okhoroni zdorov'ya Ukraïni [Special features of the implementation of the mechanisms of strategic management in the pledges of protecting the health of Ukraine]. “Aktual'nyye problemy sovremennoy nauki” sbornik tezisov nauchnykh trudov XIII Mezhdunarodnoy 
nauchno-prakticheskoy konferentsii (Khar'kov-Vena-Berlin-Astana) - "Actual problems of modern science" a collection of abstracts of scientific works of the XIII International scientific-practical conference (Kharkov-Vienna-Berlin-Astana) (pp. 53-56). Mezhdunarodnyy nauchnyy tsentr razvitiya nauki i tekhnologii [in Ukrainian].

4. Voronenko, Yu. V. (2014). Stratehichne upravlinnya v okhoroni zdorov"ya: teoretychni ta praktychni aspekty [Strategic management in health care: theoretical and practical aspects]. Naukovyy zhurnal MOZ Ukrayiny - Scientific journal of the Ministry of Health of Ukraine. № 5 (1), (pp. 39-46) [in Ukrainian].

5. Danchenko, O. B \& Lensky, V. V. (2018). Modeli stratehichnoho menedzhmentu medychnykh proektiv proektno-oriyentovanoho medychnoho zakladu [Models of strategic management of medical projects of project-oriented medical institution]. Visnyk Natsional'noho tekhnichnoho universytetu «KHPI». Seriya: Stratehichne upravlinnya - Bulletin of the National Technical University "KhPI". Series: Strategic management, portfolio management, programs and projects. № 2 (1278), (pp. 45-52) [in Ukrainian].

6. Safonov, Yu. M. \& Borsch, V. I. (2019). Stratehichnyy menedzhment zakladiv okhorony zdorov"ya Ukrayiny: pryntsypy ta osoblyvosti zastosuvannya $v$ haluzi okhorony zdorov"ya Ukrayiny [Strategic management of health care institutions of Ukraine: principles and features of application in the field of health care of Ukraine]. Aktual'ni problemy ekonomiky - Current economic problems. № 8 (218), (pp. 62-69). DOI 10.32752/1993-6788-2019-1- 218-62-69 [in Ukrainian].

7. Abdulaziz, S. (2015). «Strategic management of Healthcare Organizations». Available at: https://www.researchgate.net/publication/276019548_Strategic_management_of_Heal thcare_Organizations 